\title{
EFFECT OF HYPERTENSION ON COGNITIVE FUNCTION DISORDER AMONG THE ELDERLY IN MEDAN, NORTH SUMATERA
}

\author{
Mayang Sari Ayu'1), Faisal Balatif(1), Mahdiah²), Meri Susanti3), \\ Dewi Pangestuti4), Makmur Sinaga5)
}

\author{
1)Department of Public Health and Preventive Medicine, \\ Faculty of Medicine, Universitas Islam Sumatera Utara \\ 2)Department of Nutrition, School of Health Polytechnics, \\ Ministry of Health, Sumatera Utara \\ 3)Department of Psychiatry, Faculty of Medicine, \\ Universitas Islam Sumatera Utara \\ 4)Department of Pharmacology and Therapy, \\ Faculty of Medicine, Universitas Islam Sumatera Utara
}

5)Department of Public Health, Faculty of Public Health, Universitas Sumatera Utara

\begin{abstract}
Background: Hypertension is an increase in blood pressure that can interfere the circulation of blood flow in the brain. It can develop to be a risk factor for cognitive function disorder. The cognitive function disorders include five areas: concentration, language, orientation, memory, and attention. This study aimed to examine the effect of hypertension on cognitive function disorder among the elderly in Medan, North Sumatera.

Subjects and Method: This was a cross-sectional study conducted at 3 community health centers (Puskesmas) in Medan, North Sumatera. A total sample of 65 patients with regular anti-hypertensive treatment was selected for this study, consisting of 41 men and 24 women. Blood pressure was measured by blood pressure gauge NOVA brand. Cognitive function was measured by psychometric assessment screening using Mini Mental State Examination (MMSE). The dependent variable was cognitive function disorder. The independent variable was hypertension. The data were analyzed using chi-square test.

Results: A total of 23 (62\%) of 37 patients with level I hypertension had mild cognitive impairment, and 14 (38\%) had severe cognitive impairment. Eleven (39\%) of 28 patients with level II hypertension had mild cognitive impairment, and 17 (61\%) had severe cognitive impairment. Hypertension increased the risk of cognitive function disorder $(p=0.004)$.

Conclusion: Hypertension increases the risk of cognitive function disorder among the elderly.
\end{abstract}

Keywords: hypertension, cognitive function disorder, elderly

\section{Correspondence}

Mayang Sari Ayu. Department of Public Health and Preventive Medicine, Faculty of Medicine, Universitas Islam Sumatera Utara. Jl. STM No.77 Medan City 20146. Email: mayang1112@gmail.com/dr_mayang@yahoo.co.id. Mobile Phone: 08126554136.

The $6^{\text {th }}$ International Conference on Public Health

Best Western Premier Hotel, Solo, Indonesia, October 23-24, 2019 | 24 https://doi.org/10.26911/the6thicph.01.01 